\title{
Penyelesaian Pembagian Hak Cipta Dan Hak Atas Merek Sebagai Harta Bersama Dalam Perceraian Islam
}

\author{
Titie Rachmiati Poetri \\ Fakultas Hukum Universitas Islam Indonesia Yogyakarta Indonesia \\ Jln. Tamansiswa No.158 Yogyakarta Indonesia \\ titie.poetri99@gmail.com
}

\begin{abstract}
Assets generated in marriage are referred as joint assets or marital assets. Joint assets can be in the form of tangible or intangible objects. By using a descriptive method and a statutory approach, this normative legal research aims to analyze the following problems: first, do the copyright and trademark rights generated in a marriage qualify as joint assets according to Islamic law of marriage? Second, how to resolve the distribution of copyright and trademark rights as joint assets in divorce based on Sharia? The results of the research conclude that first, copyright and trademark rights as intangible objects become joint assets if the rights are generated in marriage, even though they are only registered in the name of either husband or wife. Second, in the event of a divorce, the copyright royalty and the right to the mark may become the object of shared joint assets, in which the royalty will be divided by two or based on the considerations of the roles and responsibilities of husband and wife during marriage.
\end{abstract}

Key Words: Copyrights; joint assets; trademark rights

\begin{abstract}
Abstrak
Harta kekayaan yang dihasilkan dalam perkawinan disebut sebagai harta bersama atau harta perkawinan. Harta bersama dapat berupa benda berwujud maupun tidak berwujud. Dengan menggunakan metode deskriptif dan pendekatan perundang-undangan, penelitian hukum normatif ini bertujuan untuk menganalisis permasalahan sebagai berikut: pertama, apakah hak cipta dan hak atas merek yang dihasilkan dalam perkawinan memenuhi syarat sebagai harta bersama menurut hukum perkawinan Islam? Kedua, bagaimana penyelesaian pembagian hak cipta dan hak atas merek sebagai aset bersama dalam perceraian Islam? Hasil penelitian menyimpulkan bahwa pertama, hak cipta dan hak atas merek sebagai benda tidak berwujud menjadi harta bersama apabila hak tersebut dihasilkan dalam perkawinan, meskipun hanya terdaftar atas nama salah satu pihak baik suami ataupun istri. Kedua, apabila terjadi perceraian, maka royalti hak cipta dan hak atas merek tersebut yang dapat menjadi objek pembagian harta bersama, yang mana royalty tersebut akan dibagi dua atau berdasarkan pertimbangan peran dan tanggungjawab suami dan istri selama perkawinan.
\end{abstract}

Kata-kata Kunci: Hak atas merek; hak cipta; harta bersama 


\section{Pendahuluan}

Hak Kekayaan Intelektual itu adalah hak kebendaan, hak atas sesuatu benda yang bersumber dari hasil kerja otak, hasil kerja rasio. ${ }^{1}$ Hak Kekayaan Intelektual merupakan bagian dari benda yaitu benda tidak berwujud sebagaimana klasifikasi benda menurut Pasal 503 KUHPerdata yaitu penggolongan benda ke dalam kelompok benda berwujud (bertubuh) dan benda tidak berwujud (tidak bertubuh). Benda immateriil atau benda tidak berwujud yang berupa hak itu dapatlah kita contoh seperti hak tagih, hak atas bunga uang, hak sewa, hak guna bangunan, hak guna usaha, hak atas benda berupa jaminan, Hak Kekayaan Intelektual (intellectual property rights) dan lain sebagainya. ${ }^{2}$

Hak Kekayaan Intelektual dapat dimiliki secara individu maupun bersama oleh dua orang atau lebih. Kepemilikan oleh dua orang atau lebih dapat dilakukan oleh orang yang terikat dalam tali perkawinan maupun yang tidak terikat dalam tali perkawinan. Ide yang telah diciptakan dalam bentuk nyata dan lahir selama pernikahan sehingga menjadi Kekayaan Intelektual maka Kekayaan Intelektual tersebut disebut sebagai harta bersama sebagaimana yang tercantum dalam Pasal 35 ayat (1) Undang-Undang Nomor 1 Tahun 1974 tentang Perkawinan jo. Undang-Undang Nomor 16 Tahun 2019 tentang Perubahan Atas Undang-Undang Nomor 1 Tahun 1974 tentang Perkawinan (untuk selanjutnya disebut Undang-Undang Perkawinan) yang dinyatakan bahwa harta benda yang diperoleh selama perkawinan menjadi harta bersama.

Harta yang diperoleh selama perkawinan tersebut atau untuk selanjutnya disebut harta bersama, dapat berupa harta benda bergerak maupun tidak bergerak, benda berwujud maupun harta benda tidakberwujud. Sebagaimana Pasal 91 Kompilasi Hukum Islam menyebutkan "harta bersama dapat berupa benda berwujud atau tidak berwujud. Harta bersama yang berwujud dapat meliputi bendatidak bergerak, benda bergerak dan surat-surat berharga. Harta bersama yang tidak berwujug dapat berupa hak maupun kewajiban. Harta bersama dapat dijadikan sebagai barang jaminan oleh salah satu pihak atas persetujuan pihak lainnya".

Hak cipta dan hak atas merek merupakan benda tidak berwujud yang berupa hak. Hal tersebut didasarkan pada nilai ekonomi dari hak tersebut yang dapat mendatangkan keuntungan materi bagi pemiliknya. Nilai ekonomi dari hak cipta dan hak atas merek diperoleh pemilik hak dari hak ekonomi dari hak cipta dan hak atas merek.

${ }^{1}$ O.K. Saidin, Aspek. Hukum Hak Kekayaan Intelektual, RajaGrafindo Persada, Jakarta, 2013, hlm. 10.

2Ibid, hlm. 13. 
Hak ekonomi adalah hak untuk memperoleh keuntungan ekonomi atas HKI. Dikatakan sebagai hak ekonomi karena HKI termasuk sebuah benda yang dapat dinilai dengan uang. ${ }^{3}$ Selain hak ekonomi, hanya hak cipta yang diberikan hak moral karena hak atas merek lahir atas dasar permintaan dari pemilik merek, maka dapat disimpulkan bahwa hak atas merek tidak mengandung suatu penghargaan atas suatu hasil kepandaian atau penemuan seseorang. ${ }^{4}$

Seorang pencipta/ pemegang hak cipta melakukan perbanyakan ciptaan kemudian dijual di pasaran, maka ia memperoleh keuntungan materi dari perbanyakan ciptaan tersebut. ${ }^{5}$

Demikian pula dengan memberi izin kepada pihak lain untuk memproduksi, memperbanyak dan menjual hasil copy-an ciptaan adalah bukan semata-mata Karena perbuatan memberi izin saja melainkan pencipta/pemegang hak cipta juga bertujuan untuk memperoleh keuntungan dari perbuatan tersebut. Hal ini memang wajar pencipta atau pemegang hak cipta ikut serta mendapat bagian keuntungan, Karena pihak yang diberi izin mendapatkan keuntungan dari penerimaan izin tersebut. ${ }^{6}$

Sama halnya dengan hak atas merek, pemilik hak atas suatu merek dapat memberikan lisensi merek tersebut kepada pihak lain baik perorangan maupun badan hukum dengan memperoleh keuntungan dari pemberian lisensi tersebut. Oleh Karena itu hak cipta dan hak atas merek berpotensi memberikan keuntungan ekonomi yang cukup tinggi, maka hak cipta dan hak atas merek sebagai harta bersama sering mengakibatkan perselisihan apabila terjadi perceraian.

Pembagian harta bersama harus berdasarkan kepada aspek keadilan bagi para pihak. Terkait atas nama siapa hak cipta dan Hak atas merek tersebut terdaftar bukan faktor bahwa apakah hak kekayaan intelektual tersebut termasuk dalam harta bersama atau tidak. Faktor yang paling penting untuk ditemukan terlebih dahulu adalah apakah harta tersebut diperoleh selama berlangsungnya perkawinan atau tidak. Selain itu apabila hak cipta dan hak atas merek tersebut terbukti ada setelah perkawinan berlangsung maka bagaimana pembagian nilai ekonomis atau royalti dari hak cipta dan hak atas merek tersebut kepada suamiistri yang akan bercerai.

${ }^{3}$ Gatot Supramono, Hak Cipta dan Aspek-Aspek hukumnya, Asdi Mahasatya, Jakarta, 2010, hlm. 45.

${ }^{4}$ Frieda Husni Hasbullah, Hukum Kebendaan Perdata: Hak-Hak Yang Memberi Kenikmatan Jilid I, Ind-Hill, Jakarta, 2002, hlm. 132.

${ }^{5}$ Gatot Supramono, Op. Cit.

${ }^{6}$ Ibid. 


\section{Rumusan Masalah}

Berdasarkan latar belakang masalah di atas maka yang menjadi pokok permbahasan dari penelitian ini adalah: Pertama, apakah hak cipta dan hak atas merek yang lahir selama perkawinan dapat dikualifikasikan sebagai harta bersama menurut hukum perkawinan Islam? Kedua, bagaimana penyelesaian pembagian Hak Cipta dan Hak Atas Merek sebagai harta bersama dalam perceraian Islam?

\section{Tujuan Penelitian}

Tujuan yang ingin dicapai dari penelitian ini adalah: Pertama, untuk mengetahui hak cipta dan hak atas merek yang lahir selama perkawinan dapat dikualifikasikan sebagai harta bersama menurut hukum perkawinan Islam; Kedua, untuk mengetahui penyelesaian pembagian Hak Cipta dan Hak Atas Merek sebagai harta bersama dalam perceraian Islam.

\section{Metode Penelitian}

Pada penelitian hukum ini, penulis penelitian yang digunakan merupakan penelitian hukum normatif. Objek penelitian berfokus kepada konsep harta bersama atau harta perkawinan menurut hukum Islam, hak cipta dan hak atas merek sebagai hak kebendaan. Penulis akan mengkaji penyelesaian pembagian hak cipta dan hak atas merek sebagai harta bersama berdasarkan sifat kebendaan dari hak cipta dan hak atas merek tersebut. Data yang diperoleh dari hasil penelitian dianalisis menggunakan teknik deskriptif. Teknik analisis dekriptif yang dimaksud bahwa peneliti berkeinginan untuk memberikan gambaran atau pemaparan atas subjek dan objek penelitian sebagaimana hasil penelitian yang dilakukannya. ${ }^{7}$

\section{Hasil Penelitian dan Pembahasan}

\section{Kualifikasi Hak Cipta dan Hak Atas Merek sebagai Harta Bersama Menurut} Hukum Perkawinan Islam

\section{Hak Cipta dan Hak Atas Merek adalah Hak Kebendaan dalam Islam}

Hak Kekayaan Intelektual menurut fiqih islam kontemporer disebut sebagai hak Ibtikar. Ibtikar secara bahasa berarti awal sesuatu atau permulaan. Ibtikar dalam fiqh Islam adalah hak kreasi atau hak cipta yang dihasilkan seseorang

\footnotetext{
${ }^{7}$ Mukti Fajar N.D. dan Yulianto Achmad, Dualisme Penelitian Hukum Normatif dan Empiris, Pustaka Pelajar, Yogyakarta, 2019, hlm. 183.
} 
untuk pertama kali, yang dalam dunia ilmu pengetahuan ibtikar dikenal dengan hak cipta. Pendapat Jumhur Ulama bila dikaitkan dengan hak ibtikar, maka hasil pemikiran, ciptaan, dan kreasi seseorang termasuk harta, karena menurut mereka, harta tidak hanya bersifat materi, tetapi juga bersifat manfaat. Atas dasar ini, maka pemikiran, hak cipta, atau kreasi yang sumbernya adalah pemikiran manusia bernilai harta dan kedudukan sama dengan benda-benda lain, seperti mobil, rumah, dan sebagainya. ${ }^{8}$

Hak atas Kekayaan Intelektual manusia yang meliputi hak cipta, penemuan atau ciri khas usaha dagang, logo, merek dagang, sistem operasional bisnis terpadu dan sebagainya dalam hukum Islam termasuk kategori hak ibtikar, yaitu penemuan atau kreasi yang merupakan hasil karya intlektual manusia yang belum pernah ditemukan oleh ilmuwan sebelumnya. Hak kekayaan intelektual bila dihubungkan dengan pengertian harta dalam hukum Islam (dalam hal ini mengacu teori Ulama Jumhur), maka Hak Kekayaan Intelektual dapat dipandang sebagai harta, karena menurut Jumhur Ulama,yang dinamakan harta tidak harus bersifat materi atau benda, tetapi juga manfaat atau hak dapat dipandang sebagai harta. Alasannya bahwa maksud orang memiliki suatu benda bukan karena semata-mata bendanya tetapi adalah manfaat dari benda itu senidiri. Atas dasar ini, maka hak atas kekayaan intlektual yang sumbernya adalah pemikiran manusia bernilai harta dan kedudukannya sama dengan kepemilikan benda-benda lain, yang berakibat bagi penemu atau pencipta terhadap karya atau ciptaannya menjadi hak milik mutlak yang bersifat materi sebagaimana dengan benda-benda lain yang dapat ditransaksikan, diwariskan atau diwasiatkan. ${ }^{9}$

Dari sini benarlah pendapat yang menyatakan bahwa manfaat adalah nilai dari sebuah harta. Jika kita tarik manfaat yang dapat dihasilkan dari sebuah hak cipta, maka kita saksikan begitu banyak manfaat yang bisa diraih darinya. Ketika hak cipta tersebut telah dituangkan ke dalam sebuah media, ia dapat menghasilkan materi (uang) yang banyak. Bahkan sering kali nilainya lebih banyak dari harta yang berupa materi.

Melihat keterangan di atas, maka HKI merupakan benda (al maal) yang berupa benda immaterial yang berupa manfaat (al manfa'ah) karena yang dilindungi bukan benda yang diciptakan, tetapi ide yang tertuang dalam suatu karya. ${ }^{10}$

${ }^{8}$ Harun, "Hak Atas Kekayaan Intelektual Perspektif Fiqih Muamalah", SUHUF, Vol. 22, No. 1, Mei 2010, hlm. 34-36.

Ibid., hlm. 38-39.

10 Budi Agus Riswandi dan Shabhi Mahmashani, Dinamika Hak Kekayaan Intelektual dalam Masyarakat Kreatif, Total Media,Yogyakarta, 2009, hlm. 137-138. 
Pada pertengahan 2005, MUI mengeluarkan fatwa, tentang perlindungan HKI. Fatwa yang dikeluarkan oleh MUI ini merupakan satu tanggapan atas kebutuhan masyarakat terkait dengan perlindungan atas hasil kekayaan intelektual. Sebagaimana disebutkan di atas bahwa dalam Al-Quran dan AlHadist memang tidak secara eksplisit disebutkan tentang HKI, akan tetapi MUI kemudian merujuk pada hasil ijtihad-ijtihad ulama terdahulu. Beberapa pendapat tersebut diantaranya adalah Majma' al-Fiqih al-Islami nomor 43 95/5) Mu'tamar V tahun $1409 \mathrm{H} / 1998 \mathrm{M}$ tentang al-Huquq al-Ma'nawiyyah yang pada intinya mengatakan bahwa merek dagang, hak cipta dan hak yang sifatnya non material sebagaimana merek dagang dan hak cipta tersebut sifatnya dipersamakan dengan hak material yang dilindungi oleh syara' sehingga hak yang sifatnya non material tersebut tidak boleh dilanggar. ${ }^{11}$

\section{Hak Cipta dan Hak atas Merek sebagai Harta Bersama dalam Islam}

Hak cipta dan hak atas merek dapat menjadi harta bersama selama hak cipta dan hak atas merek tersebut lahir selama perkawinan walaupun hak cipta dan hak atas merek tersebut terdaftar atas milik suami atau istri sebagaimana diatur dalam Pasal 35 ayat (1) Undang-Undang Perkawinan yang menyebutkan bahwa Harta benda yang diperoleh selama perkawinan menjadi harta bersama dan Pasal 1 huruf $\mathrm{f}$ Kompilasi Hukum Islam (KHI) yang menyebutkan bahwa harta kekayaan dalam perkawinan atau syirkah adalah harta yang diperoleh baik sendiri-sendiri atau bersam suami-isteri selam dalam ikatan perkawinan berlangsung selanjutnya sisebut harta bersama, tanpa mempersoalkan terdaftar atas nama siapapun.

Hak cipta dan hak atas merek, maka hak cipta dan hak atas merek dapat dikualifikasikan sebagai harta bersama, apabila hak-hak tersebut lahir selama perkawinan. Pembuktian hak cipta dan hak atas merek lahir selama perkawinan dengan cara sebagai berikut:

a. Untuk hak cipta, ide atau gagasan dari pencipta sudah diwujudkan dalam bentuk nyata sebagaimana hak cipta menganut sistem deklaratif sehingga tanpa didaftarkan ciptaan tersebut sudah mendapatkan perlindungan hukum. Namun, untuk mendapatkan legalitas sebagai pencipta, lebih baik ciptaan tersebut dicatatkan pada Direktorat Jenderal Kekayaan Intelektual (Ditjen K.I) sehingga namanya tercantum dalam daftar umum ciptaan sebagai pencipta. Ketika nama pencipta sudah tercantum dalam daftar umum ciptaan, maka pembuktian lahirnya hak cipta tersebut dapat dilihat dalam daftar catatan tersebut.

${ }^{11}$ Ibid., hlm. 142. 
b. Untuk hak atas merek, sebenarnya pendaftaran merek bukan untuk memberikan penggunaan merek tersebut. Siapapun berhak memakai merek apapun, didaftar ataupun tidak, sepanjang tidak sama dengan merek terdaftar milik orang lain di kelas dan jenis barang/jasa yang sama. Hanya saja, dengan merek terdaftar, si pemilik merek punya hak melarang siapapun untuk menggunakan merek yang sama dengan merek terdaftar miliknya untuk kelas dan jenis barang/jasa yang sama. ${ }^{12}$ Sehingga dengan merek yang telah didaftarkan maka penggunaan atas merek tersebut mendapatkan perlindungan hukum karena hanya pemilik merek terdaftar yang berhak memberikan izin untuk pemakaian merek tersebut.

Prinsip first to file yang dianut dalam sistem perlindungan Merek di Indonesia membuat siapapun - baik perorangan maupun badan hukum - yang pertama kali mendaftarkan suatu merek untuk kelas dan jenis barang/jasa tertentu, dianggap sebagai pemilik hak atas merek yang bersangkutan untuk kelas dan jenis barang/jasa tersebut. ${ }^{13}$ Oleh karena itu merek yang sudah didaftarkan lebih mudah diidentifikasi melalui Direktorat Jenderal Kekayaan Intelektual (Ditjen K.I).

Ismuha mengatakan, menurut hukum adat di Indonsia, tidaklah semua harta kekayaan suami istri merupakan kesatuan kekayaan, hanya harta kekayaan yang diperoleh bersama dalam masa perkawinan saja yang merupakan kesatuan kekayaan antara suami istri. Adapun harta mereka masing-masing yang mereka peroleh sebelum perkawinan dan harta warisan yang mereka peroleh selama perkawinan, tetap merupakan kekayaan masing-masing mereka. ${ }^{14}$

Selanjutnya Ismuha mengatakan, bahwa harta bersama pada msyarakat adat di Indonesia merupakan syirkah/perkongsian (dalam hukum Islam), dan termasuk syirkah abdan. Alasannya adalah karena sebagian besar dari suami istri sama-sama bekerja berusaha untuk mendapatkan nafkah hidup keluarga. Dulu pada masyarakat agraris, suami dan istri sama-sama turun ke ladang dan sawah, bekerja bersama-sama, sampai mereka memperoleh hasil. Sekarang, di era teknologi informasi, tidak cukup suami yang bekerja, tetapi juga dibantu oleh istri. Bahkan tidak jarang penghasilan istri lebih besar dari pada suami. ${ }^{15}$

Selain itu harta bersama juga termasuk syirkah mufawwadhah. Dikatakan demikian, karena perkongsian suami-istri itu sifatnya tidak terbatas, baik dari

12“"Merel", http://www.hki.co.id/merek.html, diakses tanggal 20 Januari 2020.

${ }^{13}$ Ibid.

14 M. Anshary, Hukum Perkawinan di Indonesia Masalab-Masalah Krusial, Pustaka Pelajar, Yogyakarta, 2010, hlm. 131-132.

15 Ibid., hlm. 133. 
segi waktu, maupun jerih payah yang dicurahkan. Inilah dasar pemikiran tentang adanya harta bersama. ${ }^{16}$

Pendapat dari ahli hukum M. Yahya Harahap menyatakan, bahwa hukum islam mengatur tentang harta bersama ini adalah sejalan dengan yang dikemukakan oleh Ismail Muhammad Syah, bahwa pencarian bersama suami dan isteri masuk dalam rub'u muamalah, tetapi ternyata secara khusus tidak dibicarakan. Hal ini mungkin disebabkan karena pada umumnya pengarang kitab-kitab fiqh adalah orang Arab yang tidak mengenal adanya adat mengenai perkongsian yang dalam Bahasa Arab disebut dengan syirkah. Oleh karena masalah pencarian bersama suami dan isteri termasuk dalam perkongsian, sebagaimana yang telah dijelaskan di atas harta bersama digolongkan syirkah abdan mufawwadhah. Berdasarkan penggolongan ini para perumus KHI melakukan pendekatan dari jalur syirkah abdan mufawwadhah dengan hukum adat. Cara pendekatan yang demikian ini tidak bertentangan dengan kebolehan menjadi urf sebagai sumber hukum dan sejiwa dengan kaidah yang mengajarkan al adatu muhakkamah. ${ }^{17}$

Harta bersama dalam Islam lebih identik diqiyaskan dengan syirkah abdan mufawwadhah yang berarti perkongsian tenaga dan perkongsian tak terbatas. Yang dimaksud dengan perkongsian tak terbatas dalam perkawinan adalah apa saja yang mereka hasilkan selama dalam masa perkawinan menjadi harta bersama, kecuali yang mereka terima sebagai harta warisan atau pemberian secara khusus kepada suami isteri tersebut. ${ }^{18}$

Harta bersama termasuk dalam syirkah abdan mufawwadhah karena dalam kenyataan yang sering terjadi di masyarkat Indonesia sebagian besar pasangan suami isteri sama-sama bekerja dalam hal mencari nafkah untuk mencukupi kebutuhan rumah tangganya. Oleh karena itu, harta bersama yang di Qiyas-kan dengan syirkah karena mengandung suatu bentuk perkongsian atau kerjasama antara suami istri. Namun, syirkah dalam harta bersama lebih kepada bentuk perkongsian untuk membangun sebuah kehidupan rumah tangga. Harta bersama dalam hal perkongsian ini sudah terjadi sejak akad nikah dinyatakan sah yang mana perkongsian terjadi dari seluruh harta suami dan istri sebagaimana konsep syirkah abdan muwafaddah yang juga tidak terbatas, maka perkongsian itu juga terjadi tanpa terbatas. Perkongsian tersebut terhadap harta benda yang

${ }^{16}$ Ibid.

${ }^{17}$ Aulia Muthiah, Hukum Islam Dinamika Seputar Hukum Keluarga, Pustaka Baru Press, Yogyakarta, 2017, hlm. 135-136.

${ }^{18}$ Ibid., hlm. 134-135. 
digunakan oleh suami dan isteri untuk membiayai kehidupan rumah tangga mereka beserta anak-anaknya.

Berdasarkan Kompilasi Hukum Islam, harta kekayaan dalam perkawinan diatur dalam Pasal 85 sampai dengan Pasal 97 pada Buku I (satu). Rumusan Pasal 85 sampai 97 Kompilasi Hukum Islam telah disetujui oleh para ahli hukum Islam di Indonesia untuk mengambil syirkah abdan sebagai landasan perumusan kaidahkaidah harta gono-gini atau harta bersama (Abdul, Manan, 2006: 111). Para perumus Kompilasi Hukum Islam melakukan pendekatan dari jalur syirkah abdan dengan hukum adat. Cara pendekatan ini tidak bertentangan dengan kebolehan menjadikan 'urf (adat/tradisi) sebagai sumber hukum dan sejalan dengan kaidah yang mengatakan "al adatu muhakkamah" (Abd. Rasyid As'ad, 2010: 6). Sebagian ahli hukum Islam memandang bahwa gono-gini merupakan kehendak dan aspirasi hukum Islam. Menurut mereka, gono-gini adalah konsekuensi dari adanya hubungan perkawinan antara seorang laki-laki dan seorang wanita yang kemudian menghasilkan harta dari usaha yang mereka lakukan berdua selama ikatan perkawinan. Mereka mendasarkan pada firman Allah di dalam Al-Qur'an Surat An-Nisa: 21 yang menyebut perkawinan sebagai suatu perjanjian yang suci, kuat, dan kokoh (mitsaqan ghalizhan). Artinya, perkawinan yang dilakukan melalui ijab qabul dan telah memenuhi syarat dan rukunnya merupakan syirkah antara suami dan istri. Oleh karena itu, akibat hukum yang muncul kemudian, termasuk harta benda menjadi milik bersama. ${ }^{19}$

\section{Penyelesaian Pembagian Hak Cipta dan Hak Atas Merek sebagai Harta Bersama dalam Perceraian Islam}

Rumusan Hasil Diskusi Komisi II Bidang Urusan Lingkungan Peradilan Agama Rakernas Mahkamah Agung RI Tahun 2007 di Makassar pada poin ketujuh menyebutkan bahwa royalti dari hasil kekayaan seseorang menjadi haknya berdasarkan hak atas kekayaan intelektual (HAKI). Dalam hal hak itu diperoleh dalam perkawinan yang sedang berlangsung, hak atas royalti menjadi pendapatan yang diperoleh dalam perkawinan dan karena itu menjadi harta bersama. Namun tidak ada penjelasan lebih lanjut lagi mengenai definisi dari royati tersebut.

Menurut Black's Law Dictionary, royalty is "A payment reserved by the grantor of a patent, lease of a mine, or similar right, and payable proportionately to the use made of the right by the grantee". Menurut Legal Dictionary "Royalty is a percentage of gross or net profit or a fixed amount per sale to which creator of a work is entitled which is

${ }^{19}$ Besse Sugiswati, "Konsepsi Harta Bersama Dari Perspektif Hukum Islam Kitab Undang-Undang Hukum Prdata dan Huku Adat”, PERSPEKTIF, Vol. XIX, No. 3, 2014, hlm. 205-206. 
determined by contract between the creator and the manufacturer, publisher, agent and/or distributor." Undang-Undang Hak Cipta "Royalti adalah imbalan atas pemanfaatan hak ekonomi suatu ciptaan atau poduk hak terkait yang diterima oleh pencipta atau pemilik hak terkait." Sehingga dapat disimpulkan royalti adalah nilai tertentu yang dibayarkan kepada pemilik hak kekayaan intelektual atas kenikmatan ekonomi dari suatu hak kekayaan intelektual, yang besarannya disepakati oleh para pihak, untuk kurun waktu tertentu. ${ }^{20}$

Keuntungan finansial atau royalti yang menjadi objek pembagian harta bersama ditentukan berdasarkan kapan lahirnya hak cipta dan hak atas merek tersebut sebagai berikut:

a. Apabila hak cipta dan hak atas merek lahir selama perkawinan sehingga keuntungan finansial dan royalti dihasilkan selama perkawinan menjadi objek pembagian harta bersama

b. Apabila hak cipta dan hak atas merek lahir selama perkawinan dan keuntungan finansial atau royalti ada setelah perceraian maka keuntungan finansial atau royalti tersebut dapat dimintakan sebagai objek pembagian harta bersama.

Apabila hak cipta dan hak atas merek terdaftar atas nama suami istri maka masing-masing tetap berhak atas hak cipta dan hak atas merek serta keuntungan finansial dan royaltinya tanpa harus adanya pembagian hak-hak tersebut sebagai objek pembagian harta bersama.

Setelah perceraian sangat mungkin royalti dari hak cipta dan hak atas merek tersebut ada selama hak ekonomi tersebut masih digunakan sebagaimana masa berlaku hak ekonomi pencipta tergantung kepada ciptaan diatur dalam Pasal 5863 Undang-Undang Hak Cipta yaitu mulai dari 25 tahun, 50 tahun, dan 70 tahun. Kemudian masa berlaku hak atas merek terdaftar sebagaimana diatur dalam Pasal 35 adalah selama 10 tahun yang dapat diperpanjang kembali dalam jangka waktu yang sama. Apabila royalti dari hak cipta dan hak atas merek sebagai harta bersama masih ada setelah perceraian maka royalti tersebut dapat diajukan untuk dimohonkan pembagiannya.

Ketentuan mengenai pembagian dan besarnya porsi perolehan masingmasing suami istri dari harta bersama apabila terjadi perceraian, baik cerai hidup maupun cerai mati atau suami atau istri hilang, kita jumpai di dalam ketentuan Pasal 96 dan Pasal 97 Kompilasi Hukum Islam (KHI). Pasal 96 KHI berbunyi sebagai berikut:

20 Dwi Anita Daruherdani, "Ketentuan dan Praktik Royalti dalam Hak Kekayaan Intelektual", http://www.iaiglobal.or.id/ diakses tanggal 20 Januari 2020. 
a. Apabila terjadi cerai mati, maka separuh harta bersama menjadi hak pasangan yang hidup lebih lama;

b. Pembagian harta bersama bagi seorang suami atau istri yang istri atau suaminya hilang harus ditangguhkan sampai adanya kepastian matinya yang hakiki atau matinya secara hukum atas dasar putusan Pengadilan Agama.

Pasal 97 berbunyi: "janda atau cerai hidup masing-masing berhak seperdua dari harta bersama sepanjang tidak ditentukan lain dalam perjanjian perkawinan".

Pasal-pasal di atas menegaskan bahwa pembagian harta bersama antara suami dan istri yang cerai hidup maupun yang cerai mati, atau karena salah satunya hilang, masing-masing mereka mendapat seperdua/setengah dari harta bersama. Tidak diperhitungkan siapa yang bekerja dan atas nama siapa harta bersama itu terdaftar. Selama harta benda itu diperoleh selama dalam masa perkawinan sesuai Pasal 35 dan 36 Undang-Undang Perkawinan, maka harta yang diperoleh tersebut merupakan harta bersama dan dibagi dua antara suami dan istri. ${ }^{21}$

Pada kasus di Pengadilan Tinggi Agama No. 126/Pdt.G/2013/PTA.JK, hakim memilih untuk tidak membagi harta bersama rata sama besar antara mantan suami dan mantan istri. Melainkan satu pertiga bagi mantan suami dan dua pertiga bagi mantan istri. ${ }^{22}$ Pertimbangan hakim memutuskan pembagian seperti itu di antaranya, karena harta bersama itu merupakan hasil jerih payah istri. Selain itu juga karena istri telah membantu melunasi pembayaran utang suami yang dibawa sebelum menikah. Serta ikut menafkahi anak-anak dari istri pertama suaminya. Sedangkan suami mendapat bagian sebagaimana di atas dengan pertimbangan masih mengurusi anak.

Pembagian harta bersama tidak serta merta mengikuti aturan normatif sebagaimana di atas, yaitu dengan 50:50 antara kedua belah pihak. Namun masih harus memperhatikan keadaan pasangan suami istri tersebut terlebih dahulu, seperti harta bawaan keduanya, pendapatannya, pemberi nafkahnya, dan lain

Pembagian dengan komposisi 50:50 belum tentu dipandang adil oleh para pihak dan putusan pengadilan dapat menentukan persentase yang berbeda berdasarkan pertimbangan keadilan hakim. Pertimbangan hakim tersebut dapat dilihat berdasarkan tanggungjawab para pihak selama perkawinan berlangsung seperti: tanggung jawab mencari nafkah keluarga, tanggungjawab mengurus

${ }^{21}$ M. Anshary, Op. Cit., hlm. 146.

${ }^{22}$ M. Syarifuddin Firdaus, "Tidak Semua Harta Selama Perkawinan Jadi Harta Bersama", https://kantorpengacara.co/tidak-semua-harta-selama-perkawinan-jadi-harta-bersama/, diakses tanggal 23 Juni 2019. 
anak, tanggungjawab mengatur harta bersama selama perkawinan berlangsung dan lainnya.

Pihak pengadilan dapat memutuskan persentase lain dengan pertimbanganpertimbangan tertentu. Misalnya atas dasar pertimbangan siapa yang mengurus dan membiayai anak, siapa yang berkontribusi terhadap harta bersama lebih besar dan siapa yang ternyata mampu mebiayai hidup sendiri. Bagaimana dengan istri yang tidak bekerja kerap mendapat perlakukan yang tidak adil dalam hal pmbagian harta bersama setelah adanya perceraian secara resmi. Sudah seharusnya istri yang tidak bekerja tetap mendapat bagian dari harta gonogininya bersama dengan suami. Alasannya, apa yang dikerjakan istri selama hidup bersama dengan suaminya adalah termasuk kegiatan bekerja juga. Hanya, memang pekerjaan istri lebih banyak berupa pekerjaan secara domestik (kerumahtanggaan), seperti mengasuh anak, memasak dan mengurus kebersihan rumah. Jadi, istri yang tidak bekerja tetap mendapat bagian dari harta bersama. ${ }^{23}$

Bagaimana pula dengan suami yang tidak bekerja (secara formal)? Berdasarkan ketentuan yang berlaku, harta bersama termasuk penghasilan istri tetap dibagi dua. Seperti halnya dengan kondisi ketika istri tidak bekerja (secara formal), maka suami yang tidak bekerja juga mendapatkan haknya dalam pembagian harta bersama. Hal itu didasarkan pada logika bahwa jika salah satu pihak tidak menghasilkan, pihak yang lain tidak bisa menghasilkan tanpa bantuan yang satunya. Artinya, meskipun salah satu dari mereka tidak bekerja secara formal, ada pekerjaan-pekerjaan lain yang itu dianggap dapat membantu urusan rumah tangga. ${ }^{24}$

Suami yang tidak bekerja secara formal perlu dilihat juga bagaimana kondisinya, apakah ia menganggur total tapi mengerjakan pekerjaan-pekerjaan domestik? Jika ternyata suami tersebut menganggur total, tetapi tidak mau mengerjakan pekerjaan-pekerjaan domestik dan harta bersama dibagi dua akan menjadi sesuatu pertanyaan besar. Apakah pembagian seperti ini bisa dikatakan adil. Untuk itulah, pembagian harta bersama juga perlu memerhatikan siapa yang berkontribusi paling besar dalam kebersamaan harta kekayaan suami-istri (harta gono-gini). ${ }^{25}$

\section{Penutup}

Adapun yang dapat disimpulkan dalam penelitian ini sebagai berikut: Pertama, hak cipta dan hak atas merek yang lahir selama perkawinan dapat

\footnotetext{
${ }^{23}$ Aulia Muthiah, Op. Cit., hlm. 141.

${ }^{24}$ Ibid.

${ }^{25}$ Ibid., hlm. 142.
} 
dikualifikasikan sebagai harta bersama karena hak cipta dan hak atas merek merupakan harta kekayaan yang dapat dimiliki seseorang, sebab hak cipta dan hak atas merek memiliki nilai ekonomi bagi pemiliknya yaitu keuntungan finansial dan royalti atas penggunaan hak-hak tersebut. Selain itu, hak cipta dan hak atas merek dapat disebut sebagai harta perkawinan atau harta bersama apabila dapat dibuktikan bahwa hak-hak tersebut lahir dalam perkawinan. Pembuktian hak cipta sebagai harta bersama apabila hak cipta dari sebuah karya yang telah dituangkan dalam wujud nyata lahir dalam sebuah perkawinan. Sedangkan pembuktian hak atas merek sebagai harta bersama apabila merek tersebut telah didaftarkan di Direktorat Jenderal Hak Kekayaan Intelektual (Dirjend.HKI) selama masa perkawinan. Meskipun Hak cipta dan hak atas merek dihasilkan atau milik salah salah satu pihak suami atau istri, hak cipta dan hak atas merek merupakan harta perkawinan atau harta bersama yang dihasilkan dari perkongsian suami istri selama perkawinan. Kedua, penyelesaian pembagian hak cipta dan hak atas merek sebagai harta bersama adalah dengan cara membagi keuntungan finansial atau royalti yang menjadi objek pembagian harta bersama ditentukan berdasarkan kapan hak cipta dan hak atas merek tersebut dihasilkan sebagai berikut: a. Apabila hak cipta dan hak atas merek lahir selama perkawinan sehingga keuntungan finansial dan royalti dihasilkan selama perkawinan menjadi objek pembagian harta bersama; b. Apabila hak cipta dan hak atas merek lahir selama perkawinan dan keuntungan finansial atau royalti ada setelah perceraian maka keuntungan finansial atau royalti tersebut dapat dimintakan sebagai objek pembagian harta bersama.

Setelah perceraian sangat mungkin royalti dari hak cipta dan hak atas merek tersebut ada selama hak ekonomi tersebut masih digunakan sebagaimana masa berlaku hak ekonomi pencipta dan hak atas merek terdaftar. Apabila royalti dari hak cipta dan hak atas merek sebagai harta bersama masih ada setelah perceraian maka royalti tersebut dapat diajukan untuk dimohonkan pembagiannya.

\section{Daftar Pustaka}

\section{Buku}

Anshary, M., Hukum Perkawinan di Indonesia Masalah-Masalah Krusial, cetakan pertama, Pustaka Pelajar, Yogyakarta, 2010.

Hasbullah, Husni Frieda, Hukum Kebendaan Perdata: Hak-Hak Yang Memberi Kenikmatan Jilid I, cetakan pertama, Ind-Hill, Jakarta, 2002.

Muthiah, Aulia, Hukum Islam Dinamika Seputar Hukum Keluarga, cetakan pertama, Pustaka Baru Press, Yogyakarta, 2017.

N.D., Mukti Fajar dan Yulianto Achmad, Dualisme Penelitian Hukum Normatif dan Empiris, Cetakan Kelima, Pustaka Pelajar, Yogyakarta, 2019. 
Riswandi, Budi Agus dan Shabhi Mahmashani, Dinamika Hak Kekayaan Intelektual dalam Masyarakat Kreatif, cetakan pertama, Total Media, Yogyakarta, 2009.

Saidin, O.K., Aspek Hukum Hak Kekayaan Intelektual, cetakan ke-sembilan, Jakarta, RajaGrafindo Persada, Jakarta, 2013.

Supramono, Gatot, Hak Cipta dan Aspek-Aspek hukumnya, cetakan pertama, Jakarta, Asdi Mahasatya, Jakarta, 2010.

\section{Jurnal}

Harun, "Hak Atas Kekayaan Intelektual Perspektif Fiqih Muamalah", SUHUF, Vol. 22, No. 1, 2010.

Sugiswati, Besse, “Konsepsi Harta Bersama Dari Perspektif Hukum Islam Kitab Undang-Undang Hukum Prdata dan Huku Adat", PERSPEKTIF, Vol. XIX, No. 3, 2014.

\section{Internet}

Daruherdani Dwi Anita, "Ketentuan dan Praktik Royalti dalam Hak Kekayaan Intelektual", http://www.iaiglobal.or.id/, diakses tanggal 20 Januari 2020

Firdaus, M. Syarifuddin, “Tidak Semua Harta Selama Perkawinan Jadi Harta Bersama", https://kantorpengacara.co/tidak-semua-harta-selamaperkawinan-jadi-harta-bersama/, diakses tanggal 23 Juni 2019.

“Merek”, http:/ / www.hki.co.id/merek.html, diakses tanggal 20 Januari 2020. 